PINTO, P. H. G.; LIMA, S. F.; ANDRADE, M. G. O.; CONTARDI, L. M.; ÁVILA, J.; REIS, B. O.; BERNARDO, V. F.; VENDRUSCULO, E. P. Weeds in soybean cultivation with different predecessor cover crops. Revista de Agricultura Neotropical, Cassilândia-MS, v. 8, n. 2, e5890, abr./jun. 2021. ISSN 2358-6303. DOI: https://doi.org/10.32404/rean.v8i2.5890.

\title{
Weeds in soybean cultivation with different predecessor cover crops
}

\section{Pedro Henrique Gomes Pinto ${ }^{1}$, Sebastião Ferreira Lima ${ }^{1}$, Maria Gabriela Oliveira Andrade², Lucymara Merquides Contardi ${ }^{3}$, Jorgiani Ávila ${ }^{2}$, Breno Oliveira Reis ${ }^{1}$, Vitória Fátima Bernardo $^{1}$, Eduardo Pradi Vendruscolo ${ }^{4}$}

\author{
${ }^{1}$ Universidade Federal de Mato Grosso do Sul, Campus de Chapadão do Sul, Mato Grosso do Sul, Brasil. E-mail: \\ pedro_gomes_pinto@hotmail.com sebastiao.lima@ufms.br, brenooliveira2014ms@gmail.com, vfbernardo@hotmail.com \\ ${ }^{2}$ Universidade Estadual Paulista, Campus de Botucatu, Botucatu, São Paulo, Brasil. E-mail: gabriela13andrade@ hotmail.com, \\ jorgianiavila@hotmail.com \\ ${ }^{3}$ Universidade Estadual Paulista, Campus de Ilha Solteira, Ilha Solteira, São Paulo, Brasil. E-mail: lu_contardi@ hotmail.com \\ ${ }^{4}$ Universidade Estadual de Mato Grosso do Sul, Cassilândia, Mato Grosso do Sul, Brasil. E-mail: agrovendruscolo@gmail.com
}

Received: 18/02/2021; Accepted: 01/04/2021.

\begin{abstract}
The competition between soybean and weeds affects crop development due to reduced resources such as water, light, and nutrients, leading to yield losses. Thus, the study aimed to evaluate quantitatively and qualitatively, through phytosociology and seed bank, the weed presence in a soybean cultivation area with different predecessor cover crops. The experiment was installed under no-till system conditions using a randomized block design with nine treatments and three replications. The treatments were composed of the following cover crops, sorghum (Sorghum bicolor), crotalaria (Crotalaria ochroleuca), millet (Pennisetum americanum), Urochloa ruziziensis, U. brizantha cv. Piatã, fodder radish (Raphanus sativus L.), U. brizantha cv. Xaraés, millet + fodder radish, and fallow. The soybean crop was established on the cover crops in the 2019/20 harvest. Soybean characteristics, the seed bank, and weed phytosociology were evaluated. The highest soybean yield was obtained with U. ruziziensis as predecessor cover crop, reaching $4530 \mathrm{~kg} \mathrm{ha}^{-1}$. It was concluded that the following cover crops, sorghum, crotalaria, and millet, were the ones that most suppressed the soil weed seed bank. Contrarily, the fallow provided the greatest viable seed number. The weed species Eleusine indica, Digitaria insularis, and Cenchrus echinatus had higher phytosociological values in all treatments.
\end{abstract}

Keywords: Glycine max, Allelopathy, Phytosociology, Seed bank.

\section{Plantas daninhas em cultivo de soja com diferentes coberturas vegetais antecessoras}

\section{RESUMO}

A competição da soja com as plantas daninhas afeta o desenvolvimento da cultura, devido à redução de recursos como água, luz e nutrientes, levando a perdas na produtividade. Assim, o objetivo do trabalho foi avaliar quantitativa e qualitativamente, por meio da fitossociologia e banco de sementes, a presença de plantas daninhas em área de cultivo de soja com diferentes coberturas vegetais antecessoras. O experimento foi instalado em sistema de semeadura direta utilizando o delineamento experimental em blocos casualizados com nove tratamentos e três repetições. Os tratamentos foram formados pelas coberturas vegetais sorgo (Sorghum bicolor), crotalária (Crotalaria ochroleuca), milheto (Pennisetum americanum), Urochloa ruziziensis, U. brizantha cv. Piatã, nabo forrageiro (Raphanus sativus L.), U. brizantha cv. Xaraés, milheto + nabo e o pousio. Sobre as coberturas vegetais foi estabelecida a cultura da soja na safra 2019/20. Foram avaliadas características da soja e o banco de sementes e fitossociologia de plantas daninhas. A maior produtividade de grãos de soja foi obtida na cobertura com $U$. ruziziensis, atingindo $4530 \mathrm{~kg} \mathrm{ha}^{-1}$. Concluiu-se que as coberturas vegetais de sorgo, crotalária e milheto foram as que mais suprimiram o banco de sementes de plantas daninhas no solo, enquanto o pousio proporcionou maior número de sementes viáveis. As espécies de plantas daninhas Eleusine indica, Digitaria insularis e Cenchrus echinatus tiveram maiores valores fitossociológicos em todos os tratamentos.

Palavras-chave: Glycine max, Alelopatia, Fitossociologia, Banco de sementes. 


\section{Introduction}

Soybean (Glycine max (L.) Merril) has become the most important legume cultivated in the world in recent years (Bornhofen et al., 2015). However, several factors contribute to yield losses, and among them, the weed presence stands out. Competition with weeds affects their development due to resource reduction such as water, light, and nutrients, decreasing their availability for the crop, causing reduced grain yield (Vasconcelos et al., 2012) and economic losses (Vendruscolo et al., 2017). Thus, cover crops having a massive and deep root system can contribute to the soil physical, chemical, and biological conditions improvement (Tokura et al., 2017) and interfere with the weed dynamics.

Cover crops are grown, generally in the off-season, specifically for the biomass production intended to cover the soil surface. It provides soil protection generating several effects such as erosion reduction, temperature and thermal amplitude, water losses through evaporation and humidity maintenance, providing considerable recycling and nutrient availability for plants grown in sequence, favoring organic material (carbon), besides causing a significant impact on reducing weed incidence (Salton and Tomazi, 2014). It becomes an economically viable alternative when considering decreasing herbicide consumption for weed control (Richetti, 2015).

Among cover crops, Pennisetum americanum (millet) is a species that has stood out, mainly for the large biomass amount produced and high drought tolerance, also providing good nutrient cycling (Pacheco et al., 2011). Fodder radish, crotalaria, and sorghum are also commonly used. Moreover, there has been an increase in perennial forage species use for soil covering, such as brachiaria (Urochloa).

They have a deep and vigorous root system, excellent adaptation to low fertility soils, easy establishment, large biomass production, and high soil surface persistence (Oliveira et al., 2011; Nascente et al., 2011). Thus, agricultural area occupation with offseason crops enhances weed suppression compared to remaining fallow areas (Castro et al., 2011; Lima et al., 2014).

When weeds are inappropriately handled in cultivated areas, they can lead to reduced yield. In addition, some of these plants may impair the harvested product quality, increasing costs and reducing the production of different crops of economic interest (Eloy et al., 2014; Coelho et al., 2016; Vendruscolo et al., 2017; Faria et al., 2018; Lima et al., 2018). These plant's emergence suppression can occur by shading, by forming a physical barrier resulting from covering accumulation deposited on the soil, and by the allelopathic effect, developed from the roots' allelochemical substances secretion or plant material decomposition (Moura Filho et al., 2015; Coelho et al., 2016)

One way to access weed plant communities' information is through phytosociological surveys, allowing us to study plant communities from a floristic and structural point of view, comparing weed populations over time and space (Pitelli, 2015; Cardoso et al., 2016). Phytosociological evaluation allows comparing weed populations through indexes such as density, relative density, frequency, relative frequency, abundance, relative abundance, and importance value index. Thus, the phytosociological survey results in a list, presenting the species in a hierarchical distribution, which allows the quantitative community structure interpretation and its ecological relationships (Concenço et al., 2013; Ferreira et al., 2014).

Another way to evaluate weeds present in a growing area is to assess your seed bank. The seed bank is a seed reserve in the soil with dynamic behavior due to the entry and exit seed processes, which will provide new individuals' supply flow to the plant communities over time (Jakelaitis et al., 2014). The seed longevity in the soil depends on the species, the environmental conditions, and depth, with dormancy representing the primary means of seed preserving (Santos et al., 2015; Cardoso et al., 2016).

Thus, knowing the size, composition, and determining factors for weed seed bank formation is essential in economic and scientific aspects since they determine agronomic techniques application for undesirable species control, besides providing the agronomic management practices anticipation (Monquero et al., 2011; Moressi et al., 2014).

Thus, this study aimed to evaluate quantitatively and qualitatively the weed presence in a soybean cultivation area with different predecessor cover crops through phytosociology and seed bank assessments.

\section{Material and Methods}

The experiment was conducted at the experimental area of the Federal University of Mato Grosso do Sul, Chapadão do Sul-MS campus, 1848'459" S, 52³6'003" $\mathrm{W}$, and 820 meters of altitude. The climate of the region is classified as humid tropical (Am-type), according to Köppen-Geiger. The annual temperature ranges between $13{ }^{\circ} \mathrm{C}$ and $28{ }^{\circ} \mathrm{C}$, the average rainfall is 1,850 $\mathrm{mm}$, with a rainfall concentration in the summer and drought in the winter (Cunha et al., 2013). During the experiment, the maximum and minimum temperatures and precipitation were observed (Figure 1).

The soil of the experimental area was classified as Latossolo Vermelho Distrófico (Santos et al., 2018), under no-tillage system conditions. 


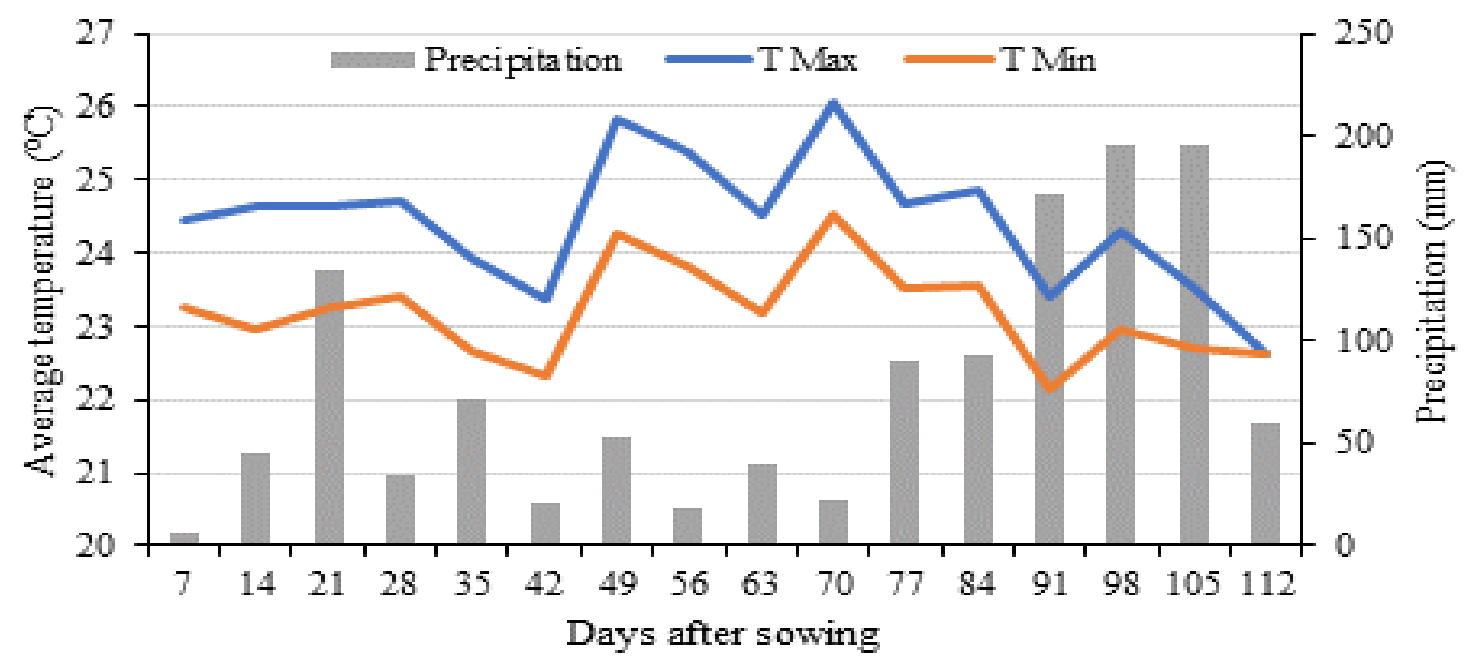

Figure 1. Maximum temperature (TMax), minimum temperature (TMin), and precipitation during the experiment conduction. Chapadão do Sul, MS, 2020. Source: INMET.

The chemical and physical soil characteristics in the experimental area, from samples collected from $0.0-0.20$ $\mathrm{m}$ deep were: clay $=40 \%$; silt $=18 \%$; sand $=42 \%$; O.M $=2.8 \% ; \mathrm{pH}\left(\mathrm{CaCl}_{2}\right)=4.6 ; \mathrm{P}($ Mehlich $)=11 \mathrm{mg} \mathrm{dm}^{-3} ; \mathrm{K}$ $=109 \mathrm{mg} \mathrm{dm}^{-3} ; \mathrm{Ca}, \mathrm{Mg}, \mathrm{Al}, \mathrm{H}$, and $\mathrm{H}+\mathrm{Al}=2.40,0.40$, $0.17,4.83$, and $5.00 \mathrm{cmol}_{\mathrm{c}} \mathrm{dm}^{-3}$, respectively; Fe, $\mathrm{Mn}, \mathrm{Zn}$, $\mathrm{Cu}$, and $\mathrm{B}=37.0,11.8,7.2,1.1$, and $0.26 \mathrm{mg} \mathrm{dm}^{-3}$, respectively.

The experimental design used was randomized blocks with nine treatments and three replications, totaling 27 plots. The treatments were formed by the following cover crops, sorghum (Sorghum bicolor), crotalaria (Crotalaria ochroleuca), millet (Pennisetum americanum), brachiaria ruziziensis (Urochloa ruziziensis), brachiaria piatã (U. brizantha cv. Piatã), fodder radish (Raphanus sativus L.), brizantha brachiaria (U. brizantha cv. Xaraés), and millet + fodder radish and fallow.

Each experimental plot consisted of an area $10 \mathrm{~m}$ long by $8 \mathrm{~m}$ wide. Cover crops were sown in March 2019. The soybean was sown in November 2019 over the area of predecessor cover crops. This experimental area is already being used in this way, under a no-tillage system for six years, with the main crop being rotated with soybeans/corn.

Cover crop sowing was done manually in furrows spaced $0.45 \mathrm{~m}$ apart, opened by a mechanized seeder, and covered by hand with a thin soil layer. No fertilization, weed control, or any other management was carried out on the cover. For the soybean crop, the plots were of the same size used in the cover crops (10 $\mathrm{x} 8 \mathrm{~m}$ ), with the useful area consisting of three rows, spaced $0.45 \mathrm{~m}$ apart, $5 \mathrm{~m}$ long, using the Nidera 5909 cultivar, with a population density of 333 thousand plants per hectare and a sowing depth from 3 to $5 \mathrm{~cm}$.

According to the ground analysis, soil correction was made with dolomitic limestone with an ECCE of
$90 \%$ in the area for soybean establishment, applying 2.1 $\mathrm{t} \mathrm{ha}^{-1}$ to raise the base saturation to $70 \%$. Before soybean sowing, the total area was desiccated using Glyphosate $\left(0.742 \mathrm{~kg} \mathrm{ha}^{-1}\right.$ a.e $)+2.4-\mathrm{D}\left(1.0 \mathrm{~kg} \mathrm{ha}^{-1}\right.$ a.i $)$. Sowing was carried out on November 12, 2019, with a mechanized four-row seeder. Together with the seed distribution, $200 \mathrm{~kg} \mathrm{ha}^{-1}$ of the triple superphosphate fertilizer $(41 \%$ $\mathrm{P}_{2} \mathrm{O}_{5}$ and $\left.12 \% \quad \mathrm{Ca}\right)$ was applied. As topdressing fertilization, at the $\mathrm{V} 4$ stage, $80 \mathrm{~kg} \mathrm{ha}^{-1}$ of $\mathrm{K}_{2} \mathrm{O}$ were applied, using potassium chloride as the source.

Imazetapir (106 g ha-1 a.i.) + Flumoxazine (50 g ha1 a.i) was applied pre-emergence weed control, and then, at the V5 stage, a Glyphosate application (720 g ha-1 a.e) was carried out. The control of caterpillars and other insects was done with three Beta-cyfluthrin $\left(10 \mathrm{~g} \mathrm{ha}^{-1}\right.$ a.i. $)+$ Imidacloprid $\left(80 \mathrm{~g} \mathrm{ha}^{-1}\right.$ a.i. $)+$ Metomil (107.5 $\mathrm{g} \mathrm{ha}^{-1}$ a.i.) applications. The fungal disease control was done with two applications of Trifloxystrobin (60 g ha ${ }^{-1}$ a.i.) + Prothioconazole (70 g $\mathrm{ha}^{-1}$ a.i.) and one application of Picoxystrobin $\left(60 \mathrm{~g} \mathrm{ha}^{-}\right.$ ${ }^{1}$ a.i.) + Ciproconazole ( $24 \mathrm{~g} \mathrm{ha}^{-1}$ a.i. $)$.

For evaluating the biomass of cover crops, $3 \mathrm{~m}^{2}$ were collected per plot of each cover crop 60 days after emergence. A sample of this material was taken and dried in a forced-air circulation oven until it reached a constant mass.

As in soybean cultivation, weed management was carried out following the cultivation pattern of the region. The phytosociological and weed bank evaluations occurred after the crop harvest. This late evaluation verifies the residual effect of the cover crops associated with the soybean cultivation in the evaluated area and guides the management sequence. The assessments were carried out by applying the hollow metal square method with an internal area of $0.25 \mathrm{~m}^{2}$ $(0.50 \times 0.50 \mathrm{~m})$, randomly launched in the plot. The 
weeds present within this framework were classified and separated into species.

The data collected during the field evaluations were used to calculate the phytosociological indexes, defined by Mueller-Dombois and Ellenberg (1974): a) Density (D): total number of individuals in a population per unit area; b) Relative Density (Dr): (density of species $x$ 100)/total density of all species; c) Frequency (F): number of squares containing the species/total number of squares obtained (total area); d) Relative frequency (Fr): (frequency of species x 100)/total frequency of species; e) Abundance (A): total number of individuals per species/total number of squares that contain the species; f) Relative abundance (Ar): (species abundance $\mathrm{x}$ 100)/total abundance of all species; g) Importance Value Index (IVI): relative frequency + relative density + relative abundance.

Ten simple soil samples were collected per plot to form the composite sample for the seed bank evaluation. The samples were taken with a $5 \mathrm{~cm}$ diameter drill, from 0 to $0.10 \mathrm{~m}$ deep. The ten simple samples were homogenized in a plastic bucket and formed the composite sample, bagged and identified. The samples were dried to the air and shade. A $1.0 \mathrm{~kg}$ aliquot from each composite sample was removed and distributed evenly in a plastic tray $(25 \times 15 \times 8 \mathrm{~cm})$. These trays were taken to the greenhouse, being irrigated as needed.

The density of individuals was obtained by observing the number of emerged seedlings in the trays, counting at fortnightly intervals. At each count, the identified seedlings were pulled out to allow a new emergency flow. Seedling emergence was observed for 60 days in four evaluations. Each sample area was obtained by the sample dry weight/soil density ratio and, subsequently, related to the emerged seedlings number from each sample to estimate the viable seeds' quantity per square meter of soil.

For the soybean cultivation, ten plants were collected into the useful area of the plot at the harvest time to determine the number of pods per plant, 100grain weight, and the mass of grains per plant. Subsequently, the entire useful area of the plot was harvested and thrashed to determine grain yield. The grain mass was adjusted to $13 \%$ moisture.

In the statistical analysis, the phytosociological data were evaluated using the indexes defined by MuellerDombois and Ellenberg (1974). The seedling densities obtained from the seed bank evaluation and the variables obtained from the soybean crop were subjected to analysis of variance. The averages were grouped by the Scott-Knott test at $5 \%$ probability. In all statistical analyses, the Sisvar software (Ferreira, 2011) was used.

\section{Results and Discussion}

The weather conditions (Figure 1) were favorable for the soybean cultivation throughout its cycle. The ideal temperature for soybean cultivation is between 20 and 30oC (Farias et al., 2007). It is observed that the maximum and minimum temperatures have always been within this range.

The water needs for the soybean to complete its cycle is between 650 and $700 \mathrm{~mm}$ (Farias et al., 2007). It is observed that there was $1254 \mathrm{~mm}$ of precipitation during the soybean cycle (Figure 1), with a considerable rainfall increase from 77 DAS. At the end of maturation, rainfall was intense, and this water availability may have contributed to greater weed manifestation from the seed bank.

The use of cover crops influenced the availability of viable weed seeds (Figure 2). The treatments with sorghum, crotalaria, and millet were the cover crops that providing less viable seed presence, reaching an average of 40.3 million seeds per hectare. This value represents a reduction of 6.6 times the value found in the fallow treatment of 264.5 million weed seeds per hectare. Meschede et al. (2007), working with these same cover crops, also observed weed suppression using cover crops compared to fallow.

On average, treatments with brachiaria resulted in 77.3 million weed seeds per hectare, leading to a 3.4-fold suppression compared to fallows. According to Fortes et al. (2018), several cover crops can have a suppressive effect on weed germination by producing biomass or their allelopathic potential, especially when these cover crops are well maintained in the soil.

Fallow was the treatment with the least potential for weed suppression. However, the cover with fodder radish was the second least efficient in this suppression, managing to suppress $37.8 \%$ of the number of seeds found in the fallow. According to Castro et al. (2011), in fallow, due to the free weed growth, without the coverage, the seed bank increases and its reinfestation in the next agricultural year, increasing the species number and the manifestation aggressiveness. This fact was also observed by Noce et al. (2008), who found a larger weed species diversity in the fallow area than in cover treatments.

The cover with sorghum provided the highest shoot dry mass $\left(8291 \mathrm{~kg} \mathrm{ha}^{-1}\right)$, followed by millet and fodder radish. The lowest cover crop mass was observed for the crotalaria (2658 $\mathrm{kg} \mathrm{ha}^{-1}$ ) (Figure 3).

Weed suppression is linked to the characteristics of cover crops. It is observed that sorghum and millet had the highest shoot dry matter values (Figure 3), reducing by 6.8 times the weed seed found in the fallow treatment. (Figure 2) 


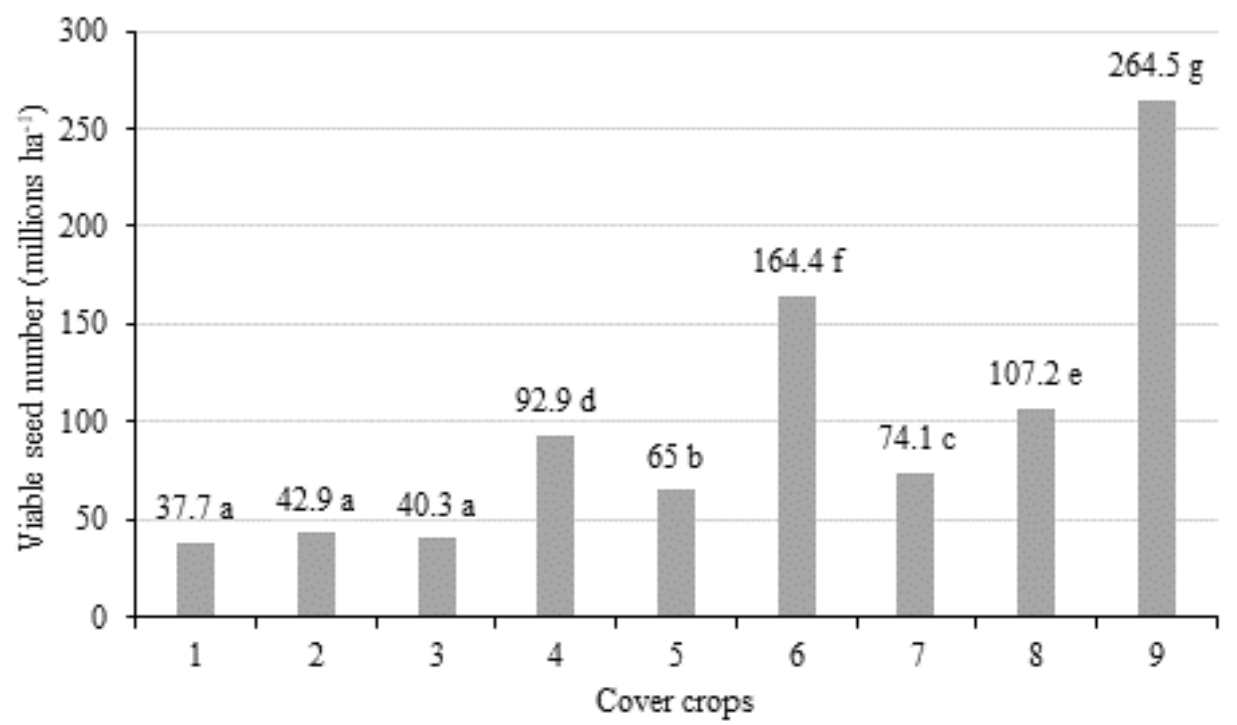

Figure 2. Number of viable weed seeds (in millions per hectare) in different cover crops before the soybean cultivation. Chapadão do Sul, 2020.

1 - sorghum (Sorghum bicolor); 2 - crotalaria (Crotalaria ochroleuca); 3 - millet (Pennisetum americanum); 4 - brachiaria ruziziensis (Urochloa ruziziensis); 5 - brachiaria piatã (U. brizantha cv. Piatã); 6 - fodder radish (Raphanus sativus L.); 7 - brizantha brachiaria (U. brizantha cv. Xaraés); 8 - millet + fodder radish, and 9 - fallow. Equal letters on the bars belong to the same group at a $5 \%$ probability by the Scott-Knott test.

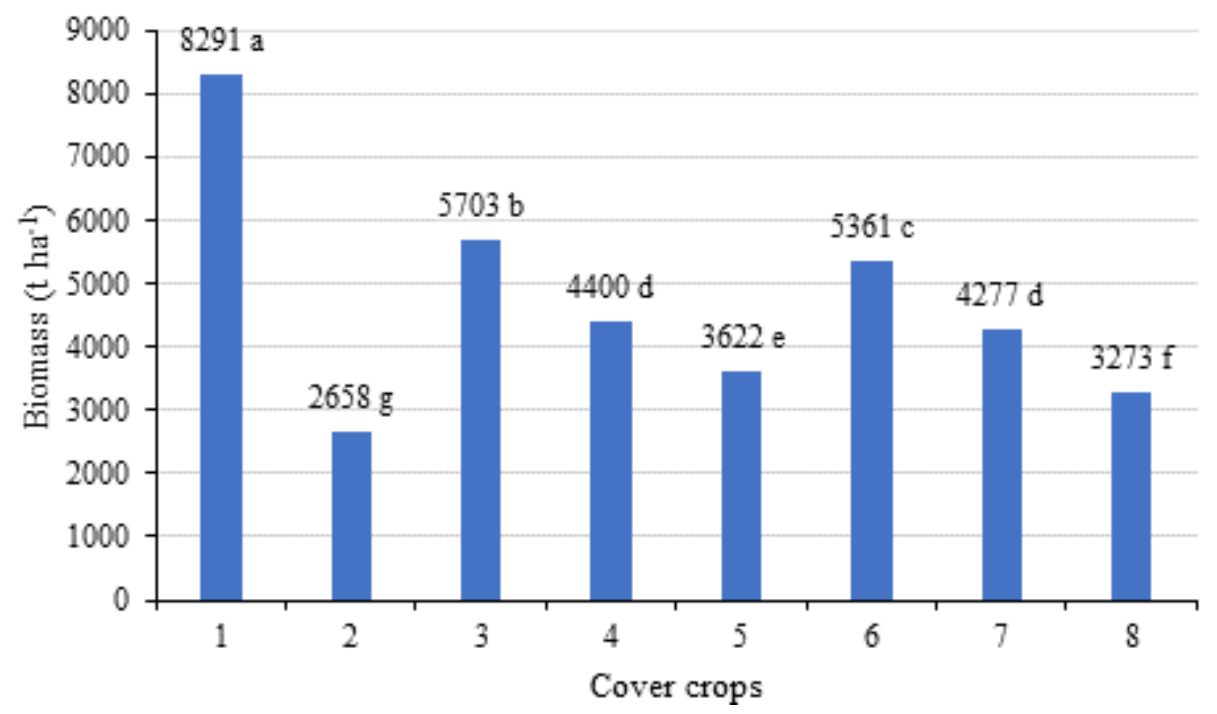

Figure 3. Shoot biomass of cover crops ( $\mathrm{t} \mathrm{ha}^{-1}$ of dry mass) preceding the soybean crop. Chapadão do Sul, 2020.

1 - sorghum (Sorghum bicolor); 2 - crotalaria (Crotalaria ochroleuca); 3 - millet (Pennisetum americanum); 4 - brachiaria ruziziensis (Urochloa ruziziensis); 5 - brachiaria piatã (U. brizantha cv. Piatã); 6 - fodder radish (Raphanus sativus L.); 7 - brizantha brachiaria ( $U$. brizantha cv. Xaraés); 8 - millet + fodder radish, and 9 - fallow. Equal letters on the bars belong to the same group at a $5 \%$ probability by the Scott-Knott test.

The high biomass production of sorghum (Lamego et al., 2015) and millet (Pacheco et al., 2011) results in soil physicochemical characteristics improvement, making it difficult weed germination due to the straw physical effect.

Despite having the lowest shoot dry mass (Figure 3), the crotalaria promoted a high reduction of weed seeds in the seed bank. It is possible that the allelopathic effect of crotalaria (Lima et al., 2007) and sorghum (Santos et al., 2012) also contributed to weed seed suppression in the soil.
Although it produced a high shoot dry mass (Figure 3 ), the fodder radish was not efficient in reducing the weed seed bank (Figure 2). It is possible that this occurs due to the rapid mass degradation on the soil, not allowing organic material persistence on the soil for a long time. Silva et al. (2007) report that fodder radish can produce high dry mass; however, with an average $\mathrm{C} / \mathrm{N}$ ratio of 21 found by Ziech et al. (2015), its residue may not persist much in the soil. Although, according to Crusciol et al. (2005), it favors a considerable nutrient release, which can be beneficial for the subsequent crop. 
Table 1 - Species of dicotyledonous and monocotyledonous weeds in the seed bank of an area with soybean cultivation in succession.

\begin{tabular}{lll}
\hline Family & Scientific Name & Popular Name \\
\hline \multicolumn{3}{c}{ Dicotyledonous } \\
\hline Asteraceae & Conyza canadensis & Horseweed \\
Lamiaceae & Leonotis leonurus & Wild dagga \\
Lamiaceae & Leonotis nepetifolia & Klip dagga \\
Malvaceae & Sida spp. & Wireweed \\
Amaranthaceae & Alternanthera tenella & Joy weed \\
\hline \multicolumn{3}{c}{ Monocotyledonous } \\
\hline Poaceae & Digitaria insularis & Sour grass \\
Poaceae & Eleusine indica & Goosegrass \\
Poaceae & Cenchrus echinatus & Southern sandbur \\
\hline
\end{tabular}

In the phytosociological survey of the cultivation area, 8 weed species were identified in 5 Families (Table 1), where the Poaceae Family with 3 species stood out. They present a more significant index among monocotyledons because they were found in the largest quantity, emphasizing Eleusina indica (crow's foot grass). According to Oliveira and Freitas (2008), Poaceae is one of the prominent weed families in grain production, sugar cane, and others. Among the dicots, two species belong to the Lamiaceae family, Leonotis leonurus (wild dagga) and Leonotis nepetifolia (klip dagga).

In the treatment with the sorghum, the weed species, E. indica, was the one that provided the highest $\mathrm{Fr}$ (50.00\%), Dr (65.22\%), Ar (48.39\%), and IVI (163.60). In crotalaria, the highest $\operatorname{Fr}(37.50 \%)$ was found with $D$. insularis. Still, the highest Dr, Ar, and 1IVI were obtained with $E$. indica (Table 2). D. insularis presented the highest Fr, Dr, and IVI in the millet, but the highest $\operatorname{Ar}$ (36.36) was reached with A. tenella. The species of $E$. indica and C. echinatus showed the highest Fr (30.00\%), and $E$. indica resulted in higher Dr, Ar, and IVI in the treatment with $U$. ruziziensis cover. The weed $D$. insularis led to the highest values of Fr, Dr, Ar, and IVI for the $U$. brizantha cv. piatã and fodder radish. In the $U$. brizantha cv. Xaraés, the highest Fr, Dr, and IVI values were observed for $D$. insularis, and the highest $\mathrm{Ar}$ (20.51\%) occurred with E. indica, C. echinatus, and $L$. leonorus.

For the millet + fodder radish, the weed $D$. insularis presented higher values of Dr, Ar, and IVI, while the presence of $D$. insularis and $C$. echinatus resulted in a higher Fr $(33.33 \%)$. In the fallow, the highest Fr value $(33.33 \%)$ was observed for the species of D. insularis and C. echinatus, the highest $\operatorname{Dr}(31.82 \%)$ and IVI (82.65) for the species C. echinatus, and the highest $\operatorname{Ar}$ (37.50) for the species L. nepetifolia.
In treatment with brachiaria, a higher IVI was found for E. indica and D. insularis species. (Table 2). In comparison, Fachinelli et al. (2021) found a higher IVI for the species of $C$. echinatus in soybean cultivated in an area with up to two years of brachiaria.

Three species of Poaceae, E. indica, D. insularis, and $C$. echinatus, presented the highest phytosociological values in all treatments, indicating that they are the most adapted species to the soil and climate conditions highly capable of competing with the covering vegetation. These weed occurrence dynamics highlight the relevance of carrying out phytosociological studies in different periods, besides the need for plant biology knowledge (Lima et al., 2014).

With the results of the phytosociological survey, it is possible to plan preventive measures and strategies for weed control and management in the cover crops to be implanted after the soybean and the subsequent harvests. In this case, consider the corn crop, which will enter into rotation with the soybean crop, providing cost and environmental impact reduction.

The use of cover crops influenced the number of pods per plant, the mass of grains per plant, and grain yield but did not affect the 100-grain weight (Table 3). Crotalaria provided a higher number of pods per plant (96.67), 15.5\% above the value obtained with fallow. It is possible that the nitrogen made available to the soil by crotalaria, due to its capacity for biological fixation (Ferreira et al., 2016), has contributed to greater plant growth and, consequently, to floral knots formation.

The mass of grains per plant showed an average of $34.17 \mathrm{~g}$ for most treatments, except for those with $U$. ruzizienses and $U$. brizantha cv. Xaraés, which presented an average mass of $27.69 \mathrm{~g}$, being $23.4 \%$ below the other treatments.

The highest soybean productivity was obtained with the $U$. ruziziensis covering, reaching $4530 \mathrm{~kg} \mathrm{ha}^{-1}$, $21.4 \%$ above the value obtained with the fallow treatment. It is possible that these brachiaria features, such as high biomass production and persistence on the soil (Oliveira et al., 2011; Nascente et al., 2011), have contributed to improving the production environment and grain yield.

Brachiaria, which provided an average grain yield of $4278 \mathrm{~kg} \mathrm{ha}^{-1}$, produced $4100 \mathrm{~kg} \mathrm{ha}^{-1}$ of shoot dry matter and reduced weed seed production in the seed bank by 3.4 times compared to fallow. Thus, besides this potential of weed suppression (Castro et al., 2011; Lima et al., 2014), they also improve the soil microbiological characteristics (Simon et al., 2019), which may have favored this higher grain yield. 
Table 2 - Number of presences in the squares (NS), number of individuals (NI), frequency (F), relative frequency (Fr), density (D), relative density (Dr), abundance (A), relative abundance (Ar) and importance value index (IVI) of weed species collected in sorghum cover in succession to soybean.

\begin{tabular}{|c|c|c|c|c|c|c|c|c|c|}
\hline \multicolumn{10}{|l|}{ Sorghum } \\
\hline Species & NS & NI & $\mathrm{F}$ & $\operatorname{Fr}(\%)$ & $\mathrm{D}$ & $\operatorname{Dr}(\%)$ & $\mathrm{A}$ & $\operatorname{Ar}(\%)$ & IVI \\
\hline E. indica & 4 & 15 & 1 & 50.00 & 3.75 & 65.22 & 3.75 & 48.39 & 163.60 \\
\hline D. insularis & 2 & 5 & 0.5 & 25.00 & 1.25 & 21.74 & 2.50 & 32.26 & 79.00 \\
\hline A. tenella & 2 & 3 & 0.5 & 25.00 & 0.75 & 13.04 & 1.50 & 19.35 & 57.40 \\
\hline TOTAL & 8 & 23 & 2 & 100 & 5.75 & 100 & 7.75 & 100.00 & 300.00 \\
\hline \multicolumn{10}{|l|}{ Crotalaria } \\
\hline E. indica & 2 & 8 & 0.5 & 25.00 & 2 & 47.06 & 4.00 & 46.15 & 118.21 \\
\hline D. insularis & 3 & 5 & 0.75 & 37.50 & 1.25 & 29.41 & 1.67 & 19.23 & 86.14 \\
\hline C. bonariensis & 1 & 2 & 0.25 & 12.50 & 0.5 & 11.76 & 2.00 & 23.08 & 47.34 \\
\hline A. tenella & 2 & 2 & 0.5 & 25.00 & 0.5 & 11.76 & 1.00 & 11.54 & 48.30 \\
\hline TOTAL & 8 & 17 & 2 & 100.00 & 4.25 & 100.00 & 8.67 & 100.00 & 300.00 \\
\hline \multicolumn{10}{|l|}{ Millet } \\
\hline E. indica & 2 & 2 & 0.5 & 22.22 & 0.50 & 11.11 & 1.00 & 12.12 & 45.45 \\
\hline D. insularis & 4 & 9 & 1 & 44.44 & 2.25 & 50.00 & 2.25 & 27.27 & 121.72 \\
\hline A. tenella & 1 & 3 & 0.25 & 11.11 & 0.75 & 16.67 & 3.00 & 36.36 & 64.14 \\
\hline L. leonurus & 2 & 4 & 0.5 & 22.22 & 1.00 & 22.22 & 2.00 & 24.24 & 68.69 \\
\hline TOTAL & 9 & 18 & 2.25 & 100 & 4.50 & 100 & 8.25 & 100 & 300 \\
\hline \multicolumn{10}{|c|}{ Urochloa ruziziensis } \\
\hline E. indica & 3 & 8 & 0.75 & 30.00 & 2.00 & 50.00 & 2.67 & 38.10 & 118.10 \\
\hline D. insularis & 1 & 1 & 0.25 & 10.00 & 0.25 & 6.25 & 1.00 & 14.29 & 30.54 \\
\hline C. bonariensis & 1 & 1 & 0.25 & 10.00 & 0.25 & 6.25 & 1.00 & 14.29 & 30.54 \\
\hline C. echinatus & 3 & 4 & 0.75 & 30.00 & 1.00 & 25.00 & 1.33 & 19.05 & 74.05 \\
\hline A. tenella & 2 & 2 & 0.50 & 20.00 & 0.50 & 12.50 & 1.00 & 14.29 & 46.79 \\
\hline TOTAL & 10 & 16 & 2.50 & 100 & 4.00 & 100 & 7.00 & 100 & 300 \\
\hline \multicolumn{10}{|c|}{ Urochloa brizantha cv. Piatã } \\
\hline E. indica & 1 & 1 & 0.25 & 20.00 & 0.25 & 10.00 & 1.00 & 14.29 & 44.29 \\
\hline D. insularis & 2 & 6 & 0.50 & 40.00 & 1.50 & 60.00 & 3.00 & 42.86 & 142.86 \\
\hline C. echinatus & 1 & 2 & 0.25 & 20.00 & 0.50 & 20.00 & 2.00 & 28.57 & 68.57 \\
\hline A. tenella & 1 & 1 & 0.25 & 20.00 & 0.25 & 10.00 & 1.00 & 14.29 & 44.29 \\
\hline TOTAL & 5 & 10 & 1.25 & 100 & 2.50 & 100 & 7.00 & 100 & 300 \\
\hline \multicolumn{10}{|l|}{ Fodder radish } \\
\hline E. indica & 2 & 3 & 0.5 & 28.57 & 0.75 & 27.27 & 1.50 & 27.27 & 83.12 \\
\hline D. insularis & 3 & 6 & 0.75 & 42.86 & 1.5 & 54.55 & 2.00 & 36.36 & 133.77 \\
\hline C. echinatus & 1 & 1 & 0.25 & 14.29 & 0.25 & 9.09 & 1.00 & 18.18 & 41.56 \\
\hline A. tenella & 1 & 1 & 0.25 & 14.29 & 0.25 & 9.09 & 1.00 & 18.18 & 41.56 \\
\hline TOTAL & 7 & 11 & 1.75 & 100 & 2.75 & 100 & 5.50 & 100 & 300 \\
\hline \multicolumn{10}{|c|}{ Urochloa brizantha cv. Xaraés } \\
\hline E. indica & 2 & 4 & 0.50 & 20.00 & 1.00 & 23.53 & 2.00 & 20.51 & 64.04 \\
\hline D. insularis & 4 & 7 & 1.00 & 40.00 & 1.75 & 41.18 & 1.75 & 17.95 & 99.13 \\
\hline C. echinatus & 1 & 2 & 0.25 & 10.00 & 0.50 & 11.76 & 2.00 & 20.51 & 42.28 \\
\hline A. tenella & 1 & 1 & 0.25 & 10.00 & 0.25 & 5.88 & 1.00 & 10.26 & 26.14 \\
\hline L. leonurus & 1 & 2 & 0.25 & 10.00 & 0.50 & 11.76 & 2.00 & 20.51 & 42.28 \\
\hline L. nepetefolia & 1 & 1 & 0.25 & 10.00 & 0.25 & 5.88 & 1.00 & 10.26 & 26.14 \\
\hline TOTAL & 10 & 17 & 2.50 & 100 & 4.25 & 100 & 9.75 & 100 & 300 \\
\hline \multicolumn{10}{|c|}{ Millet + Fodder radish } \\
\hline E. indica & 1 & 1 & 0.25 & 16.67 & 0.25 & 5.26 & 1 & 9.52 & 31.45 \\
\hline D. insularis & 2 & 12 & 0.50 & 33.33 & 3 & 63.16 & 6 & 57.14 & 153.63 \\
\hline C. echinatus & 2 & 5 & 0.50 & 33.33 & 1.25 & 26.32 & 2.5 & 23.81 & 83.46 \\
\hline L. nepetefolia & 1 & 1 & 0.25 & 16.67 & 0.25 & 5.26 & 1 & 9.52 & 31.45 \\
\hline TOTAL & 6 & 19 & 1.50 & 100 & 4.75 & 100 & 10.5 & 100 & 300 \\
\hline \multicolumn{10}{|l|}{ Fallow } \\
\hline E. indica & 1 & 3 & 0.25 & 11.11 & 0.75 & 13.64 & 3.00 & 22.50 & 47.25 \\
\hline D. insularis & 3 & 6 & 0.75 & 33.33 & 1.50 & 27.27 & 2.00 & 15.00 & 75.61 \\
\hline Sida spp. & 1 & 1 & 0.25 & 11.11 & 0.25 & 4.55 & 1.00 & 7.50 & 23.16 \\
\hline C. echinatus & 3 & 7 & 0.75 & 33.33 & 1.75 & 31.82 & 2.33 & 17.50 & 82.65 \\
\hline L. nepetefolia & 1 & 5 & 0.25 & 11.11 & 1.25 & 22.73 & 5.00 & 37.50 & 71.34 \\
\hline TOTAL & 9 & 22 & 2.25 & 100 & 5.50 & 100 & 13.33 & 100 & 300 \\
\hline
\end{tabular}


Table 3. Number of pods per plant (NPP), 100-grain weight (100W), mass of grains per plant (MGP), and grain yield (YIELD) of soybean according to the predecessor cover crops.

\begin{tabular}{lllll}
\hline Treatments & NPP & $100 \mathrm{~W}$ & MGP & YIELD \\
\hline Sorghum & $88.33 \mathrm{~b}$ & $17.53 \mathrm{a}$ & $34.03 \mathrm{a}$ & $4286 \mathrm{~b}$ \\
Crotalaria & $96.67 \mathrm{a}$ & $17.50 \mathrm{a}$ & $35.67 \mathrm{a}$ & $3962 \mathrm{c}$ \\
Millet & $86.67 \mathrm{c}$ & $18.33 \mathrm{a}$ & $33.57 \mathrm{a}$ & $3806 \mathrm{~d}$ \\
U. ruziziensis & $90.33 \mathrm{~b}$ & $17.93 \mathrm{a}$ & $26.10 \mathrm{~b}$ & $4530 \mathrm{a}$ \\
U. brizantha cv. Piatã & $89.33 \mathrm{~b}$ & $17.10 \mathrm{a}$ & $32.53 \mathrm{a}$ & $3986 \mathrm{c}$ \\
Fodder radish & $84.33 \mathrm{c}$ & $17.43 \mathrm{a}$ & $37.60 \mathrm{a}$ & $4054 \mathrm{c}$ \\
U. brizantha cv. Xaraés & $88.67 \mathrm{~b}$ & $17.90 \mathrm{a}$ & $29.27 \mathrm{~b}$ & $4318 \mathrm{~b}$ \\
Millet + Fodder radish & $80.33 \mathrm{c}$ & $17.93 \mathrm{a}$ & $33.07 \mathrm{a}$ & $4056 \mathrm{c}$ \\
Fallow & $83.66 \mathrm{c}$ & $17.73 \mathrm{a}$ & $32.70 \mathrm{a}$ & $3732 \mathrm{~d}$ \\
\hline Mean & 87.59 & 17.71 & 33.84 & 4081 \\
\hline CV & 3.11 & 1.99 & 8.75 & 2.13 \\
\hline
\end{tabular}

Means followed by the same lowercase letters in the column belong to the same group at 5\% probability by the Scott-Knott test.

\section{Conclusions}

The following cover crops, sorghum, crotalaria, and millet, most suppressed the soil weed seed bank. In contrast, fallow provided the greatest number of viable seeds.

The weed species Eleusine indica, Digitaria insularis, and Cenchrus echinatus had higher phytosociological values in all treatments.

Cover crops affected the number of pods and the mass of grains per plant. With Urochloa ruziziensis as vegetable covering, the highest soybean grain yield was obtained.

\section{Authors' Contribution}

Pedro Henrique Gomes Pinto: preparation, conception, design, and data acquisition; Sebastião Ferreira de Lima: preparation, conception, design, data analysis, and interpretation; Maria Gabriela de Oliveira Andrade: preparation, conception, and design; Lucymara Merquides Contardi, Jorgiani Ávila, Vitória Fátima Bernardo and Breno de Oliveira Reis: preparation, conception, and design; Eduardo Pradi Vendruscolo: preparation, conception, design, data analysis, and interpretation.

\section{Acknowledgments}

To the CNPq for the granting of a scientific initiation scholarship.

\section{Bibliographic References}

Bornhofen, E., Benin, G., Galvan, D., Flores, M.F. 2015. Épocas de semeadura e desempenho qualitativo de sementes de soja. Pesquisa Agropecuária Tropical, 45(1), 46-55. https://doi.org/10.1590/1983-40632015v4529143

Cardoso, I.S., Soares, M.P., Araujo, V.T., Cabral, P.H.R., Jakelaitis, A., Madalão, J.C. 2016. Bank of weed seeds in agrosystems in the brazilian cerrado. Planta Daninha, 34(3), 443-451. https://doi.org/10.1590/s0100-83582016340300005

Castro, G.S.A., Crusciol, C.A.C., Negrisoli, E., Perim, L. 2011. Sistema de produção de grãos e incidência de plantas daninha. Planta Daninhas, 29(n. spe), 1001-1010. https://doi.org/10.1590/S0100-83582011000500006

Coelho, S.P., Galvão, J.C.C., Campos, S.A., Trogello, E., Pereira, L.P.L., Barrella, T.P., Cecon, P.R., Pereira, A.J. 2016. Coberturas vegetais na supressão de plantas daninhas em sistema de plantio direto orgânico de milho. Revista Brasileira de Milho e Sorgo, 15(1), 65-72. https://doi.org/10.18512/19806477/rbms.v15n1p65-72

Concenço, G., Tomazi, M., Correia, I.V.T., Santos, S.A., Galon, L. 2103. Phytosociological surveys: tools for weed science? Planta Daninha. 31(2), 469-482. https://dx.doi.org/10.1590/S0100-83582013000200025

Cunha, C.C., Magalhães, F.F., Castro, M.A. 2013. Métodos para estimativa da evapotranspiração de referência para Chapadão do Sul - MS. Engenharia na Agricultura, 21(2), 159172. https://doi.org/10.13083/reveng.v21i2.346

Crusciol, C.A.C., Cottica, R.L., Lima, E.V., Andreotti, M., Moro, E., Marcon, E. 2005. Persistência de palhada e liberação de nutrientes do nabo forrageiro no plantio direto. Pesquisa Agropecuária Brasileira, 40(2), 161-168. https://dx.doi.org/10.1590/S0100-204X2005000200009

Eloy, E., Caron, B.O., Trevisan, R., Monteiro, G.C., Elli, E.F., 2014. Período adequado de controle de plantas invasoras em plantios florestais. Revista Ciência da Madeira, 5(2), 80-84. https://doi.org/10.12953/2177-6830.v05n02a01

Fachinelli, R., Melo, T.S., Capristo, D.P.; Abreu, H.K.A., Ceccon, G. Weeds in soybean crop after annual crops and pasture. Revista de Agricultura Neotropical, 8(1), e5563. https://doi.org/10.32404/rean.v8i1.5563

Faria, J.T., Gonçalves, E.O., Delarmelina, W.M., Assumpção, C.M., Caldeira, M.W., 2018. Influência da mato-competição de capim-braquiária no crescimento inicial de espécies florestais em plantio misto. Revista de Ciências Agroambientais, 16(1), 62-71. https://doi.org/10.5327/rcaa.v16i1.1449

Farias, J.R.B., Nepomuceno, A.L., Neumaier, N. 2007. Ecofisiologia da soja. Londrina: Embrapa Soja. 
https://www.infoteca.cnptia.embrapa.br/handle/doc/470308 (acessado 10 de fevereiro de 2021)

Ferreira, A.C.B., Bogiani, J.C., Sofiatti, V., Lamas, F.M. 2016. Sistema de cultivo de plantas de cobertura para a semeadura direta do algodoeiro. Campina Grande: Embrapa Algodão. https://www.infoteca.cnptia.embrapa.br/infoteca/bitstream/doc /1066067/1/Sistemasdecultivodeplantasdecobertura.pdf (acessado 10 de fevereiro de 2021)

Ferreira, D.F. 2011. Sisvar: A computer statistical analysis system. Ciência e Agrotecnologia, 35(6), 1039-1042. https://doi.org/10.1590/S1413-70542011000600001

Ferreira, E.A., Fernandez, A.G., Souza, C.P., Felipe, M.A., Santos, J.B., Silva, D.V., Guimarães, F.A.R. 2014. Levantamento fitossociológico de plantas daninhas em pastagens degradadas do Médio Vale do Rio Doce, Minas Gerais. Revista Ceres, 61(4), 502-510. https://doi.org/10.1590/0034-737X201461040008

Fortes, C.T., Galon, L., Beutler, A.B., Basso, F.J.M., Nonemacher, F., Reichert Júnior, F.W., Perin, G.F., Tironi, S.P. 2018. Soil management systems and their effects on the weed seed bank. Pesquisa Agropecuária Brasileira, 53(4), 435-442. https://doi.org/10.1590/s0100-204×20180000400005

Jakelaitis A., Soares, M.P., Cardoso, I.S. 2014. Banco de sementes de plantas daninhas em solos cultivados com culturas e pastagens. Revista Global Science and Technology, 7(2), 6373. http://dx.doi.org/10.14688/1984-3801/gst.v7n2p63-73

Lamego, F.P., Caratti, F.C., Reinehr, M., Gallon, M., Santi, A.L., Basso, C.J. 2015. Potencial de supressão de plantas daninhas por plantas de cobertura de verão. Comunicata Scientiae, 6(1), 97-105. https://doi.org/10.14295/cs.v6i1.470

Lima, C., Pereira, L.M., Mapeli, N.C. 2007. Potencial alelopático de crotalária, feijão-de-porco e gergelim na germinação e desenvolvimento inicial de picão-preto (Bidens pilosa). Revista Brasileira de Agroecologia, 2(2), 1175-1178. http://revistas.aba-

agroecologia.org.br/index.php/cad/article/download/2730/237 2/ (acessado em 15 de fevereiro de 2021)

Lima, S.F., Timossi, P.C., Almeida, D.P., Silva, R.U. 2014. Fitossociologia de Plantas daninhas em convivência com plantas de cobertura. Revista Caatinga, 27(2), 37-47. https://periodicos.ufersa.edu.br/index.php/caatinga/article/vie w/3353 (acessado em 15 de fevereiro de 2021)

Lima, S.F., Timossi, P.C., Brod, E., Teixeira, I.R., Silva, J.A. 2018. Matocompetição na cultura de Crambe abysinica cultivado em safra e safrinha. Cultura Agronômica: Revista de Ciências Agronômicas, 27(3), 297-311. https://doi.org/10.32929/2446-8355.2018v27n3p297-311

Meschede, D.K., Ferreira, A.B., Ribeiro Junior, C.C. 2007. Avaliação de diferentes coberturas na supressão de plantas daninhas no cerrado. Plantas Daninhas, 25(3), 465-471. https://doi.org/10.1590/S0100-83582007000300005

Monquero, P.A., Silvia, P.V., Hirata, A.C.S., Martins, F.R.A. 2011. Monitoramento do banco de sementes de plantas daninhas em áreas com cana-de-açúcar colhida mecanicamente. Planta Daninha, 29(1), 107-119. https://doi.org/10.1590/S0100-83582011000100013
Moressi, M., Padovan, M.P., Pereira, Z.V. 2014. Banco de sementes como indicador de restauração em sistemas agroflorestais multiestratificados no sudoeste de Mato Grosso do Sul, Brasil. Revista Árvore, 38(6), 1073-1083. https://doi.org/10.1590/S0100-67622014000600012

Moura Filho, E.R., Macedo, L.P.M., Silva, A.R.S. 2015. Levantamento fitossociológico de plantas daninhas em cultivo de banana irrigada. Holos, 2(1), 92-97. https://doi.org/10.15628/holos,2015.1006

Muller-Dombois, D., Ellenberg, H. 1974. Aims and methods of vegetation ecology. New York: John Wiley e Sons. https://www.researchgate.net/publication/259466952_Aims_a nd_methods_of_vegetation_ecology. (acessado em 15 de fevereiro de 2021 )

Nascente, A.S., Kluthcouski, J., Rabelo, R.R., Oliveira, P., Cobucci, T., Crusciol, C.A.C. 2011. Desenvolvimento e produtividade de cultivares de arroz de terras altas em função do manejo do solo. Pesquisa Agropecuária Tropical, 41(2), 186192. https://doi.org/10.5216/pat.v41i2.6980

Noce, M.A., Souza, I.F., Karam, F., França, A.C., Maciel, G.M. 2008. Influência da palhada de gramíneas forrageiras sobre o desenvolvimento da planta de milho e das plantas daninhas. Revista Brasileira de Milho e Sorgo, 7(3), 265-278. http://dx.doi.org/10.18512/1980-6477/rbms.v7n3p265-278

Oliveira, A.R., Freitas, S.P. 2008. Levantamento fitossociológico de plantas daninhas em áreas de produção de cana-de-açúcar. Planta daninha, 26(1), 33-46. https://doi.org/10.1590/S0100-83582008000100004

Oliveira, P., Kluthcouski, J., Favarin, J.L., Santos, D.C. 2011. Consórcio de milho com braquiária e guandu-anão em sistema de dessecação parcial. Pesquisa Agropecuária Brasileira, 46(10), 1184-1192. https://doi.org/10.1590/S0100-204X2011001000010

Pacheco, L.P., Leandro, W.M., Machado, P.L.O.A., Assis, R.L., Cobucci, T., Madari, B.E., Petter, F.A. 2011. Produção de fitomassa e acúmulo e liberação de nutrientes por plantas de cobertura na safrinha. Pesquisa Agropecuária Brasileira, 46(1), 17-25. https://doi.org/10.1590/S0100-204X2011000100003

Pitelli, R.A. 2015. O termo planta-daninha. Planta Daninha. 33(3), 622-623. https://doi.org/10.1590/S010083582015000300025

Richetti, A. 2015. Viabilidade econômica da cultura da soja na safra 2012/2013, em Mato Grosso do Sul. Dourados: Embrapa Agropecuária Oeste. https://ainfo.cnptia.embrapa.br/digital/bitstream/item/632 32/1/COT2012177.finaslpdf.pdf (acessado 10 de fevereiro de 2021)

Salton, J.C., Tomazi, M. 2014. Sistema Radicular de Plantas e Qualidade do Solo. Dourados: Embrapa Agropecuária Oeste. https://www.infoteca.cnptia.embrapa.br/bitstream/doc/100532 6/1/COT198.pdf (acessado 10 de fevereiro de 2021)

Santos, H.G., Jacomine, P.K.T., Anjos, L.H.C., Oliveira, V.A., Lumbreras, J.F., Coelho, M.R., Almeida, J.A., Araujo Filho, J.C., Oliveira, J.B., Cunha, T.J.F. 2018. Sistema Brasileiro de Classificação de Solos. Brasília: Embrapa. https://www.embrapa.br/solos/sibcs. (acessado em 10 de fevereiro de 2021) 
Santos, I.L.V.L., Silva, C.R.C., Santos, S.L., Maia, M.M.D. 2012. Sorgoleone: benzoquinona lipídica de sorgo com efeitos alelopático na agricultura como herbicida. Arquivos do Instituto Biológico, 79(1), 135-144. https://doi.org/10.1590/S1808-16572012000100020

Santos, R.C., Ferreira, E.A., Santos, J.B., Oliveira, M.C., Silva, D.V., Pereira, G.A.M., Galon, L., Aspiazu, I., Mattos, N.P. 2015. Phytosociological characterization of weed species as affected by soil management. Australian Journal of Crop Science, 9(2), 112119. https://www.researchgate.net/publication/282949569 Phytosociological_characterization_of_weed_species_as_affected _by_soil_management. (acessado 10 de fevereiro de 2021)

Silva, A.A., Silva, P.R.F., Suhre, E., Argenta, G., Strieder, M.L., Rambo, L. 2007. Sistemas de coberturas de solo no inverno e seus efeitos sobre o rendimento de grãos do milho em sucessão. Ciência Rural, 37(4), 928-935. http://dx.doi.org/10.1590/S0103-84782007000400002

Simon, C.A., Lima, S.F., Cordeiro, M.S., Secco, V.A., Nacata, G., Silva, A.M.M., Simon, C.C., Brasil, M.S. 2019. Cover crops as modying agentes of microbiological soil attribute. Australian Journal of Crop Science, 13(10), 1578-1585. https://doi.org/10.21475/ajcs.19.13.10.p1723
Tokura, L.K., Secco, D., Zanão Junior, L.A., Siqueira, J.A.C., Santos R.F., Martins, M.F.L., Alovisi, A.M.T., Oliveira, L.C., Hojo, R.H., Pereira, N., Pilatti, M.A., Moreira, M.C.D.L., Villa, B., Schmatz, M.J. 2017. Structuring potential of some cover crops and crambe in Haplortox under no-tillage system. African Journal of Agricultural Research. 12(24), 20782086. http://dx.doi.org/10.5897/AJAR2016.11725

Vasconcelos, M.C.C., Silva, A.F.A, Lima, R.S. 2012. Interferência de plantas daninhas sobre plantas cultivadas. Agropecuária Científica no Semiárido, 8(1), 01-06. http://dx.doi.org/10.30969/acsa.v8i1.159

Vendruscolo, E.P., Campos, L.F.C., Arruda, E.M., Seleguini, A. 2017. Análise econômica da produção de alface crespa em cultivo sucessivo de plantas de cobertura em sistema de plantio direto. Revista Brasileira de Ciências Agrárias, 12(4), 458-463. https://doi.org/10.5039/agraria.v12i4a5478

Ziech, A.R.D., Conceição, P.C., Luchese, A.V., Balin, G.C., Garmus, T.G. 2015. Proteção do solo por plantas de cobertura de ciclo hibernal na região Sul do Brasil. Pesquisa Agropecuária Brasileira, 50(5), 374-382. https://doi.org/10.1590/S0100-204X2015000500004 